\title{
The Right of the Dissolution of Parliament in the Jordanian and Kuwaiti Parliamentary System ( A Comparative Study)
}

\author{
Dr. Khalid Khalaf Al-Droa \\ Assistant Professor of Public Law, Jadar University - College of Law
}

\begin{abstract}
The right to dissolve parliament in the parliamentary system is one of the most significant means of influence that the executive branch exercises in its relationship with the legislative branch. It is the constitutional weapon that the executive branch use in facing the second authority which can raise the political responsibility of the ministry and brings it down. The executive branch can terminate the life of the parliament before the end of its term as it has the right to dissolve it by resorting to the will of the sovereign people in the dispute between the legislative and executive branches over matters of state policy through early parliamentary elections. The Jordanian Constitution of 1952 and its amendments and the Kuwaiti Constitution of 1962 stipulated a number of conditions that prevent the abuse of the right of dissolution by the executive authority.Despite of the importance of these conditions, some of them still insufficient and the others are incompatible with the purpose of dissolving the parliament.
\end{abstract}

Keywords: dissolution of parliament, legislative branch, executive branch, ministerial responsibility, parliamentary system.

DOI: $10.7176 / J L P G / 90-10$

Publication date:October $31^{\text {st }} 2019$

\section{Introduction}

The parliamentary system is the most ancient and prevalent political system in the world ${ }^{(1)}$.The Hashemite Kingdom of Jordan and the State of Kuwait adopt the parliamentary system although the constitutional provisions of the two states have not explicitly provided this, the study of the constitutional provisions contained in both constitutions - Jordan and its amendments, - The Jordanian Constitution of 1952 and its amendments, and the Kuwaiti Constitution of 1962 and its amendments.

It clearly demonstrates the existence of the characteristics of the parliamentary system represented by the bicameral system of the executive branch (the king and the ministry) in Jordan, and (the prince and the ministry) in Kuwait.And the lack of responsibility of the President of the State. ${ }^{(2)}$

On the other hand,the existence of a parliament elected by the citizens which is called The House of Representatives (Majlis al-Nuwwab) in Jordan and (the National Assembly) in Kuwait. In addition to the existence of mutual control, balance and cooperation between the executive and legislative authorities, and manifestation of this control is the responsibility of the government before the parliament, which has the right to put confidence in the government or to bring it down.

This is offset by the right of the executive branch to dissolve the parliament, which is comprised of two Champers:the House of Representative (Majlis al-Nuwwab) and the House of The House of Senate (Majlis alA'yan). ${ }^{(3)}$

Where in Kwuiat it comprised of one Assembly that is known as the National Assembly.

Article (34) of the Jordanian Constitution of 1952 and its amendments provide for the right of the King to dissolve the House of Representative in its both chambers.

Article (107) of the Kuwaiti Constitution of 1962 and its amendments provide for the right of the Emir to dissolve the National Assembly.

The right to dissolve Parliament is based on an essential democratic principle, based on the will of the sovereign people in the dispute between the legislative and executive branches over one of the issues related to the general policy of the State.

Where the executive authority resorted to the exercise of this right, when its relationship with the parliament reached a dead end, threatening to disrupt constitutional life and obstruct the work of state bodies. Thus, it resorts to dissolve parliament before the end of its constitutional term, and early parliamentary elections are held,

If the result of these elections is the re-election of the members of the dissolved parliament, it means that

${ }^{1}$ Arnous, Gh,S (2017) The Reality of the Application of the Principle of Commitment between Power and Responsibility, First Edition, Dar Al-Hurun Al-Alami, Amman,p. 475.

${ }^{2}$ Thnibat,M,J (2003) Political Systems and Constitutional Law (with Analytical Explanation of the Jordanian Constitutional System: Rights and Freedoms, first edition.Darr al Thakafa ,Amman p.246.

${ }^{3}$ Adaileh ,A,S (2010) Brief in the constitutional system, first edition, House of Culture, Amman,p52. 
the people support the position of the legislature,

If the result of the elections is that the members of the dissolved parliament are not elected, it means that the people support the position of the government, which will be supported by the majority in the new parliament, which gives it strength during the performance of its functions as it is based on the support of the people.

\section{The importance of the research}

The importance of this research is that it sheds light on one of the most important and dangerous constitutional means that the executive authority has in its relationship with the legislative authority in the parliamentary system, under which it has the power to terminate the life of the Legislative Council before the end of its term, and resort to early elections to gain the opinion of the people on the controversial issue concerning the general policy of the state, which arises between the executive and legislative branches.

\section{Research Objective}

This research aims at identifying the right to dissolve parliament, its types, and the justifications that lead the executive authority to resort to it. It also aims at studying the extent of adequacy of the provisions, constitutional controls and guarantees relating to the right to dissolve parliament stipulated by the current Jordanian and Kuwaiti Constitution and compare them.

\section{Research problem}

Although both the current Jordanian and Kuwaiti constitutions have included several conditions and conditions that must be met in order to dissolve parliament constitutionally to achieve the purpose of the dissolution which is to invoke the will of the sovereign people in the disputes that may arise between the executive and legislative powers, but some of these conditions may appear in sometimes insufficient or incompatible with the purpose of adopting the right of dissolution.

\section{Research Methodology}

The researcher will follow the comparative analytical approach, through studying and analyzing the constitutional texts related to regulating the exercise of the executive power of this right in both the Jordanian and Kuwaiti constitutions, the conditions included in these texts and then comparing them.

\section{Topic One}

\section{What is the right to dissolve parliament and its justifications?}

The parliamentary system is based on a flexible separation between the executive and legislative branches with overlapping and cooperation in exercising the state functions and exchanging a balanced influence between them (1)

The right to dissolve Parliament represents a constitutional weapon of the executive power and corresponding to the political responsibility of the Government before Parliament ${ }^{(2)}$.It protects the executive power from the dominance of the legislature power and maintains a balance between the two powers ${ }^{(3)}$

Just as parliament can overthrow the government, it can also overthrow the parliament and appeal to the people in the dispute between them and the legislative branch on one of the public policy issues of the state. ${ }^{(4)}$

The researcher will try to clarify the concept of the right to dissolve parliament and its type in the first section and the justification of dissolving the parliament in the second one.

\section{Section I.The concept of the right to dissolve parliament and its types}

The birth of the right to dissolve parliament was initiated in England, which is considered the cradle of the parliamentary system, where this right was a privilege of the English King ${ }^{(5)}$ but this right has developed into the jurisdiction of the government then it was adopted by the countries which follow parliamentary system including the Hashemite Kingdom of Jordan, and the State of Kuwait, where each State has organized it through special constitutional provisions explaining the conditions, conditions and guarantees for the exercise of this right. The researcher will try to clarify the concept of the right to dissolve parliament, and the types of dissolution of parliament through the following:

\footnotetext{
${ }^{1}$ Bana,M,A (1988) the Mediator in Political Systems, First Edition, Dar Al-Fikr Al-Arabi, Cairo, p.198.

${ }^{2}$ Murzeh,I(2015) Constitutional Law (A Comparative Study of the Libyan Constitution and the Constitutions of Other Arab Countries), 2nd ed.Dar al Kutob for production ,p 407

${ }^{3}$ Mitwali,A (1964) Constitutional Law and Political Systems, Part I, 3d Edition, Cairo,318.

${ }^{4} \mathrm{Baz}$, B, Ali (2000) The Right to Dissolve Parliament in Contemporary Constitutions, (Comparative Study), Ph.D. Thesis submitted to Tanta University, p. 57

${ }^{5}$ Adaileh ,A,S ,Op.Cit p.91
} 
1. The concept of the right to dissolve parliament:

There have been many definitions given by scholars to the right to dissolve parliament .

One of the jurists defined the right to dissolve parliament as: "The desire of the ministry submitted to the President of the State to request the termination of the term of Parliament in order to resort to the rule of the people in the event of a serious disagreement between them and the Parliament ${ }^{(1)}$ ".

It was also defined as "The right of the executive branch to terminate the parliament's prosecution before its term, ie before the end of the legislative term ${ }^{(2)}$ ". Another definition is "Termination of the term of the House of Representatives before the end of the period specified for the legislative term. ${ }^{(3)}$ "

One of the best definitions is that the right to dissolve parliament is: "legal action taken by the executive branch to end the life of the Legislative Council before the expiry of the term for which it was elected, in order to seek public opinion on a particular issue of great importance in the course of political life for the country ${ }^{(4)}$. The researcher supports this definition as it obviously clarifies the meaning of the right to dissolve parliament and the purpose of exercising it.

The Jordanian Constitution of 1952 and its amendments stipulated the King's right to dissolve the National Assembly (the representative and Senate) in paragraphs (3) and (4) of Article (45). The Kuwaiti Constitution of 1962 in Article (107) also stipulates that the Amir shall enjoy the same right.

The positions of the jurists on the right to dissolve the parliament have contradicted, some of them opposed it ${ }^{(5)}$ while others support it ${ }^{(6)}$. This right is based on a genuine democratic principle of invoking the sovereign citizens to know their opinion on the dispute between the government and parliament. There is no room for discussing the arguments of each group, but no matter how different the views are, all the countries that have adopted the parliamentary system consider the executive branch right to dissolve parliament ${ }^{(7)}$.

2. Types of the dissolution of parliament

The right of dissolution emerged at the beginning in England in its royal form, this dissolution is called the presidential dissloution, and then as a result of the historical developments that followed the English parliamentary system, the ministerial dissolution emerged, and these two types are the two most common types in the constitutions of the contemporary world.

Although some constitutions provide for the possibility of Parliament dissolving itself, which is called selfdissolution, and other constitutions have delegated the power to dissolve Parliament to the people through the socalled popular or referendum dissolution ${ }^{(8)}$.

The researcher will discuss the presidential and ministerial dissolution because of their importance, popularity and relevance.

A) Presidential dissloution:

A presidential dissolution is usually resorted to as a result of a dispute between the head of state (king, emir, or president of the republic) and the parliament, with each party believing that it reflects the reality of public opinion.In this case, if the Parliament has given its confidence to the Cabinet, the Head of State shall dismiss the cabinet which is supported by the parliamentary majority, assign another Cabinet that has the confidence of the minority or even outside parliament to run the affairs of the country, and upholds its position in dissolving the parliament $^{(9)}$.

The President of the State exercises this type of dissolution as one of his authorities, where the right to dissolve is one of the most important competencies exercised by the Head of State in the parliamentary system, as it is of great importance in maintaining a balance between the executive power, which he holds.

and the legislative power vested in Parliament ${ }^{(10)}$.It was the last implementation of the presidential dissolution in England without the request and advice of the Prime Minister in 1834, and since then the English King no longer exercises this right, which led many scholars and jurists to consider that it is dropped for not being exercised any more. ${ }^{(11)}$

\footnotetext{
${ }^{1}$ Jeeraneh, M, Z(1936) Notes on Constitutional Law, 1st ed., Al-Ahd Press, Baghdad . p. 11

${ }^{2}$ Leila, M, K(1970) Political Systems (State and Government), 1st ed.Dar al fiker al Arabi,Cairo,p 641.

${ }^{3}$ Muslim, Kh, A (1997) The Right to Solution in the Parliamentary System, (Comparative Study) PhD Thesis, Cairo University.

${ }^{4}$ Bahri, H,M(2014)The Legal Encyclopedia, Part I, First Edition, Presidency of the Republic of Syria, 1125, p. 534

${ }^{5}$ See Sadiq, M(1925) Principles of Egyptian and Comparative Constitutional Law, 1st ed., Dar al-Kitab al-Arabi, Cairo, , p. 299 et seq. Alexandria, Also Sheha, (2006), The Status of the Executive in Contemporary Political Systems, First Edition, Al-Ma'arif Establishment, Alexandriap.78.

${ }^{6}$ See this: Sabri, S(1937) Notes on Constitutional Law, 1st ed., (Without mentioning a publishing house), Cairo, p.298.and also Fahmi, M(1985), The Egyptian Constitution and the Constitutional Control of Laws, 1st ed., Ma'aref Establishment, Alexandria, p. 485.

${ }^{7}$ Abu Zeid, M,A (1988)Dissolution of the House of Representatives (Comparative Study), First Edition, Dar Al-Nahda Al-Arabiya, Cairo, pp 31-33.

${ }^{8}$ Nawalti, B, M (2014) Dissolution of Parliament in Comparative Political Systems, Master Thesis submitted to Damascus University, p. 37

${ }^{9}$ Tamawi, S, M(1996), The Three Authorities in Contemporary Arab Constitutions and Islamic Political Thought, (Comparative Study), 6th Edition, Ain Shams Press.p 526.

${ }^{10}$ Bahri, H,M ,Op ,cit p 325.

${ }^{11}$ Ali, I, (1982) Head of State in the Democratic System (PhD Thesis), Cairo University, Faculty of Law, p. 138.
} 
B) Ministerial dissolution:

In this case, the dissolution of the Parliament shall be at the request of the Ministry, with the aim of arbitrating the people in the dispute that arises between them and the Parliament. As with the royal dissolution, a ministerial dissolution can only be done by a decree or royal decree issued by the head of state signed by the prime minister and the competent minister. However, the head of state does not work alone in the parliamentary system, as he exercises his powers after the prime minister and the minister or competent ministers have signed his decree. This type of dissolution is currently in force in Britain, where parliament is dissolved at the request of the Prime Minister, usually when there is a dispute between the government and parliament, such as the decision to withdraw confidence from the ministry as a result of a dispute over one of the issues of public policy, the latter believes that it is right and that the majority of the House of Representatives is intransigent. Accordingly, It asks the President to dissolve Parliament as an indirect means of referendum the citizens in the conflict that led to the withdrawal of confidence from the Ministry. On the advice of the Prime Minister, the President of the State (the King) issues a resolution to dissolve the Parliament and invites the electorate to elect new members. If the result of the general elections is the same as the previous parliamentary majority, the matter will be decided in favor of the parliament, but if this majority does not come again (i.e. the elections came by a majority in favor of the dissolved ministry), this means that the ministry was right to hold on to its opinion. On the subject of the dispute $^{(1)}$.

The Council of Representatives in Jordan, whether presidential or ministerial, shall be dissolved by a Royal Decree signed by the competent Minister and the Prime Minister, and the King shall prove his signature above the previous signatures ${ }^{(2)}$.

However, it should be noted that following the constitutional amendments that took place in the Hashemite Kingdom of Jordan on 5/5/2016 the dissolution of the Senate was made by royal will without the signature of the Prime Minister or the competent ministers. ${ }^{(3)}$

\section{Section II. The Justifications for dissolving Parliament}

The justification for dissolving the parliament varied,it may be resorted to because of a dispute between the government and the parliament, or between the head of state and the parliament on one of the public policy issues. Thus, parliament is dissolved to arbitrate the citizens in the dispute that has arisen between the executive and legislative branches. It can be used to solicit public opinion on important issues of state policy, or to support the parliamentary majority. We will address these justifications through the following:

I) Dissolution of Parliament due to the conflict between the executive and legislative branches.

The parliamentary system is based on cooperation between the executive and legislative branches ${ }^{(4)}$.However, a dispute between the two branches may occur with having no chance to reconcile them which may obstruct the functioning of the state bodies and threatens the public interest.Therefore, the executive branch resorts to the right of dissolution as a means to know the opinion of the citizens in the dispute between it and the legislative branch.Taking his opinion on this controversial issue, which is expressed by what the French jurist Esseman said: "The right to a dissolution is the best way to resolve the dispute that may arise between the public authorities in the state and it is one of the peaceful means that can be used to resolve the dispute without violence $^{(5)}$.

This type of dispute is the most common form of conflicts that can occur between the government and parliament.An example of this dissolution in Kuwait's constitutional and political history was the dissolution of the third Kuwaiti National Assembly on May 4, 1999, the Fourth National Assembly on 21/5/2006, the Fifth Assembly of the Nation on 19/3/2008.

The Sixth National Assembly was dissolved on 18 March 2009 due to the political escalation between the government and representative, and the frequent interrogations to the Cabinet.

The seventh National Assembly was dissolved on 6/12/2011 as a result of the bribery scandal of the representative and the frequent interrogations of the prime minister and the ministers ${ }^{(6)}$

2) Dissolution of Parliament to solicit public opinion on important issues:

It is crucial to recognize the public's opinion on the important issues of state policy and how to manage its affairs to achieve a consensus between the work of the executive branch and the hopes and aspirations of the people.

The head of state may dissolve parliament to seek public opinion on these issues and to identify their

\footnotetext{
${ }^{1}$ Bahri, H,M .op.cit .pp 327-329.

${ }^{2}$ Shatnawi, A, Kh(2013) Political Systems and Jordanian and Comparative Constitutional Law, Book III: The Jordanian Constitutional System, First Edition, Wael Publishing House, Amman ,p.379.

${ }^{3}$ Khatib, N, A (2017)The Simple in the Constitutional System, Second Edition, Dar Al-Thaqafa, Amman, p. 156

${ }^{4}$ Muslim, Kh, op.cit., P. 97

${ }^{5}$ Abdul Mut'al, A(2004) Dissolution of Parliament in Comparative Constitutional Systems, 1st ed.Dar al Nahdah,Cairo,p 197.

${ }^{6}$ Website of Kuwait Today Newspaper, Issue No. 292, Thirty-second Year:www. Portal.media.gov.kw
} 
position on them.

Definitely, some parliamentary states that are not permitted by the rules of the parliamentary system to referendum its people may resort to dissolving parliament as an indirect means referendum the citizens polling on fundamental reforms affecting the entity of the political or economic system of the state ${ }^{(1)}$

3) The dissolution of the Parliament to Support the Parliamentary Majority

It is possible to resort to dissolving the parliament or one of its two chambers to find an explicit and stable parliamentary majority that stands beside the executive authority and supports it to ensure the stability of the government and to prevent recurrent ministerial crises,particularly in the case of authorship governments.

If the seats distributed in the parliament among the different parties do not make one of them clearly superior to the others, and a stable parliamentary majority cannot be formed,it is advisable to dissolve the existing parliament aiming that the new elections will produce the required parliamentary majority,

However, the exercise the right to dissolve in this case is dangerous as the government may lose power if the new elections are not in its favor. ${ }^{(2)}$

Therefore, after we got acquainted with the concept of the right to dissolve parliament and its types, and the justifications for the executive authority to dissolve parliament,we proceed to examine how the Jordanian and Kuwaiti constitutions regulated and control the exercise of the right to dissolve.

\section{Topic Two}

The Constitutional organization of the right to dissolve parliament in the Jordanian and Kuwaiti parliamentary systems.

However, this right has evolved under the successive Jordanian constitutions.Notably, the previous Jordanian constitutions stipulated the right of the President of the State to dissolve Parliament, but without giving sufficient guarantees. This is evident in Article (19) of the Basic Law of 1928, and Article (26/c) of the Constitution of 1946.

The current Constitution of 1952 provides for this right in Article (34) thereof, and has given it a number of constitutional conditions to guarantee the safe use of its Constitutional amendments of 1952 in Articals (73) and (74). ${ }^{(3)}$

The situation in Kuwait is not very different from the situation in Jordan.According to the Constitution of 1938 by which the Head of State combines the presidency of the legislative and executive branches,However, this right was absolute from any restriction, the Prince exercised this right without any restriction or guarantee. ${ }^{(4)}$

However,after the current constitution has been implemented since 29/12/1962, the right of dissolution and its conditions have been stipulated in Article (107) in a similar way as it is stated in the current Jordanian Constitution and its amendments of 1952.

The researcher will try to shed light on the conditions and guarantees related to the right of dissolution, as stated in the current Jordanian and Kuwaiti constitution, through the following:

\section{Section 1: Conditions related to the decision of dissolving the parliament}

The Jordanian Constitution of 1952 and its amendments, and the Kuwaiti Constitution of 1962 and its amendments, require a number of conditions and guarantees to take the decision to dissolve the parliament, as specified that certain conditions must be met, otherwise it is considered void for violating the Constitution. These conditions are:

1. Issuance of the dissolution decision by the President of the State in accord to the constitutional conditions.

Paragraph (3) Article (34) of the Jordanian Constitution and its amendments stipulated that "The King may dissolve the Chamber of Deputies." Paragraph (4) of the same article provided that "The King may dissolve the Senate or relieve any Senator of his membership." While paragraph (1) of Article (40) required that "The King shall exercise the powers vested in him by Royal Decree. Every such Decree shall be countersigned by the Prime Minister and the Minister or Ministers concerned. The King expresses his concurrence by placing his signature above the said signatures. "The competent minister, in this case is the Minister of Interior. In 1955 the House of Representatives was dissolved by a royal will signed by the Prime Minister only, and then presented the matter to the Supreme Council for the interpretation of the Constitution, which decided that the will does not meet the constitutional requirements for being free from the signature of the Minister of the Interior, considering it void. ${ }^{(5)}$ In accord to the recent constitutional amendments in the Hashemite Kingdom of Jordan of 5/5/2016, the Royal Decree related to the dissolution of the Senate, does not require the signature of the Prime Minister or the

\footnotetext{
${ }^{1}$ Kanaan, N(2013) Principles of Constitutional Law and the Jordanian Constitutional System (in accordance with the Constitutional Amendments of 2011), First Edition, Ithraa for Publishing and Distribution, Amman,p. 153.

${ }^{2}$ Abdul Mut'al, A ,op.cit .p.167.

${ }^{3}$ Adaileh ,A,S ,Op.Cit p.51

${ }^{4}$ Muslim, Kh, op.cit., Pp 256-257.

${ }^{5}$ Decision of the Supreme Council for the Interpretation of the Constitution No. (1) Official Gazette No. 1255 Date5/1/1956
} 
competent ministers.

While in Kuwait, the National Assembly is dissolved by a decree signed by the Emir, in accordance with Article (107) of the Kuwaiti Constitution of 1962.

2. Mentioning the reasons of the decision of dissolving parliament and the inadmissibility of dissolving it for the same reason:

The decision to dissolve parliament,which is represented by the Royal Decree in Jordan, or the Emiri Decree in Kuwait, is one of the administrative decisions

However, it is not subject to appeal to the Administrative Court because it is an act of sovereignty which was confirmed by the former Supreme Court in one of its decisions ${ }^{(1)}$,

Originally,administrative decisions do not require mentioning the reasons unless there is a provision stipulated so ${ }^{(2)}$.Therefore, Both the Jordanian Constitution of 1952 and its amendments and the Kuwaiti Constitution of 1962 and its amendments stipulate the necessity of causing the decision to dissolve, although the Jordanian Constitution implicitly stated this whereas the Kuwaiti Constitution explicitly stipulates this ${ }^{(3)}$. It shall be reasoned, that is, including the legal and factual reasons that led the executive to issue it, since causing the dissolution is an important legal guarantee, so that the public can know the real reasons for issuing the dissolution. ${ }^{(4)}$

Paragraph (1) Article (74) of the amended Jordanian Constitution of 1952 states: "If the Chamber of Deputies is dissolved for any reason, the new Chamber shall not be dissolved for the same reason." This constitutional clause provides a guarantee that the dissolution of the Champer will not be repeated for the same reason as the previous one.

Thus, this condition is consistent with the purpose of the right to dissolve, but dissolving the parliament in itself means a return to the original rule or the citizens to express their opinion in the dispute between the legislative and executive authorities or in any other matter for which the Council was dissolved, if the citizens decide through the new parliamentary elections, their decision must be respected.

Consequently, the new Champer may not be dissolved for the same reason as the previous one, otherwise the new dissolution would violate the people's decision ${ }^{(5)}$.

This is expressed by saying: "The dissolution is not permissible on the dissolution." (6)

\section{Section 2.Other conditions}

Despite the importance of the regulations related to the decision of the dissolution, which is issued by the President of the State, summoning his constitutional conditions, the need to causing it and not to repeat the dissolution of parliament for the same reason, but the current Jordanian Constitution and the Kuwaiti Constitution have been keen to increase these controls, in recognition of the constitutional legislator in both countries granted to the executive authority. Such conditions include:

1- The election of the new Parliament must be held within a specified period:

Constitutional legislators are keen to prevent the executive champer from abusing the right to dissolve parliament.They also ensure that the right of dissolution does not disrupt the political life of the country or impede the functioning of the State bodies, which may threaten the safety and security of the country and hinders its development,

Therefore, the Jordanian Constitution of 1952 stipulated in paragraph (1) of the amended article (73) that: "If the Chamber of Deputies is dissolved, a general election shall be held, and the new Chamber shall convene in an extraordinary sessions not later than four months from the date of dissolution. Such session shall be deemed to be an ordinary session in accordance with the provisions of Article 78 of the present Constitution and shall be subject to the conditions prescribed therein in respect of prolongation or adjournment."

The Kuwaiti Constitution in Article (107) that "if the Council is dissolved, elections for the new Council shall be held no later than two months after the date of dissolution ...".

To prevent the executive authority from abusing the right to dissolve the House of Representatives, the Jordanian Constitutional Legislator has taken it as a pretext to disrupt parliamentary life in the country. And in order that the provisions concerning the necessity of holding new parliamentary elections on the dates specified in the Constitution are no longer mere texts the provisions of Article (73) of the amended Jordanian Constitution paragraph (2) stipulate: "If no elections have taken place by the end of the four months, the dissolved Chamber shall assume its full constitutional powers and assemble forthwith as if its dissolution had not taken place. It shall remain in office until the election of a new Chamber..."

\footnotetext{
${ }^{1}$ Decree No. 340/1997, published in the Official newspaper, No. 226 dated 1/9/1997, p. 150

${ }^{2}$ Shobaki, O, M (2016)Administrative Judiciary, (Comparative Study), Fifth Edition, Dar Al-Thaqafa, Amman, p. 297

${ }^{3}$ Hassan, A F(1986)The Principles of the Constitutional System in Kuwait, First Edition, Dar Al-Nahda Al-Arabiya, Cairo, p. 381.

${ }^{4}$ Shatnawi, A,Kh, op. Cit., P. 348

${ }^{5}$ Tamawi, S, M.op,cit ,p 536

${ }^{6}$ Abu Zeid, M,A,pp 186-187.
} 
The Kuwaiti Constitution in Article (107) stated "If no elections have taken place, the dissolved Chamber shall assume its full constitutional powers and assemble forthwith as if its dissolution had not taken place. It shall remain in office until the election of a new Chamber."

This guarantee is a means of pressure on the executive branch to hold parliamentary elections within the constitutionally determined dates. $^{(1)}$

2- The Resignation of the Ministry Under which the Parliament Dissolves

Paragraph (2) of Article (74) of the amended Jordanian Constitution of 1952 states: "The government in which the Champer of Representatives dissolves shall resign within a week from the date of dissolution, and its president may not be entrusted with the formation of the next government." Kuwait's constitution did not include a similar condition.

In fact, when constitutions require the exercise of the right to dissolve parliament, the resignation of the ministry under which the parliament was dissolved is intended not to interfere with the ministry that accepted the dissolution, or demanded the head of state. In the general elections, and not affecting them to and ensure the success of its candidates who agree to the view of the head of state if he is the one who wanted the dissolution, and this condition requires the formation of a neutral ministry to oversee elections to ensure that the dissolved ministry does not intervene in the elections. ${ }^{(2)}$

Despite the importance of this condition of exercising the right to dissolve parliament, the researcher believes that the Jordanian constitutional legislator has overstated when it stipulated that the head of the government, which the House of Representatives was dissolved at its period may not be assigned to form the next ministry, because this contradicts the purpose for which the dissolution of Parliament has embarked on a constitutional provision such as this, which constitutes an individual punishment for the prime minister alone and not the rest of the ministers who are entitled to hold ministerial positions in the government formed after the dissolution decision. ${ }^{(3)}$ It will also lead realistically to the reluctance of the Prime Minister to ask the King to dissolve the House of Representatives whatever the size of the dispute between the Ministry and the Champer and whatever the Champer committed mistakes, for fear of losing his position.

Finally, after discussing the conditions of exercising the right to dissolve parliament in the constitutional systems of Jordan and Kuwait, we must not ignore the great role played by ministerial political responsibility as a weapon against the right to dissolve the parliament, which is considered by many jurists a characteristic of the parliamentary system, it prohibits both the individual and solidarity abuse of the executive power to dissolve the parliament, but the result of this responsibility is the withdrawal of confidence from the minister or his Cabinet or dropped it, which is a similar result to the result of the right to dissolve parliament.

\section{Conclusion}

At the end of our study the right to dissolve parliament in both the Jordanian and Kuwaiti parliamentary systems, in which we identified this dangerous weapon retained by the executive power in the parliamentary system, in contrast with what the legislative authority has especially influencing on the political responsibility of the ministry, where the right to dissolve the parliament the end of its term. The Executive Authority resorts to exercise it if the dispute between it and the Parliament reaches a dead end, with a view to invoking the opinion of the citizens, which is reflected in the results of the new parliamentary elections, and after we have known the justifications for the use of this right and its regulations in the Jordanian and Kuwaiti constitutions, it is necessary to state the findings and recommendations as follow:

\section{RESULTS}

1 The right to dissolve parliament is the weapon of the executive power in the parliamentary system in contrast with the political responsibility of the ministry, which leads to a balance between the executive and legislative branches, and it is a characteristic of the parliamentary system that adopts a flexible separation of powers.

2 The executive's use of the right to dissolve parliament is intended to invoke the opinion of the sovereign people in a dispute between them and the legislative power on a matter of state policy.

3 In countries with parliamentary systems, such as Jordan and Kuwait, the constitutional legislator is keen to establish regulations governing the use of the right to dissolve parliament in a manner that prevents abuse of executive power, contrary to its purpose.

4 The House of Representatives in Jordan shall be dissolved by a Royal Decree signed by the Prime Minister and the competent Minister, the Minister of Interior. While the dissolution of the Senate shall be by a sole royal decree that does not need to be signed by any other party other than the King. In Kuwait The National Assembly is dissolved by a decree signed by the Emir.

\footnotetext{
${ }^{1}$ Shatnawi, A,Kh, op. Cit., P. 412

${ }^{2}$ Baz, B, Ali ,op.cit .p 105.

${ }^{3}$ Nassraween, L, K. Government Resignation after the Dissolution of the House of Representatives, an article published in Jordan's Al-

Dustour Newspaper, dated 17 September 2019 on the website:www.alrai.com> article
} 
5 The decision to dissolve parliament must reveal its causes so that public opinion can ascertain the seriousness and constitutionality of the reasons that prompted the executive to use it.

6 It is not permissible to repeat the dissolution of Parliament for the same reason it was dissolved, because it opposed to the will of the sovereign people and impedes the political life of the country.

\section{Recommendations}

In the light of what has been presented in this research and the results, the researcher recommends the following:

- The researcher calls on the Jordanian and Kuwaiti constitutional legislators to provide for the executive authority to take the advice of a competent authority, such as the Constitutional Court in Jordan, before the dissolution of the parliament, to ensure the compatibility of the dissolution decision with the provisions of the Constitution.

- The researcher calls on the Jordanian and Kuwaiti constitutional legislators to provide for the reduction of the duration of the new parliamentary elections following the dissolution of parliament to one month instead of four months in Jordan and two months in Kuwait, especially since in the era of technology, preparation for the elections is held quickly. Because the current periods are long and lead to the disruption of political life in the country.

- The researcher calls on the Jordanian and Kuwaiti constitutional legislators to stipulate that the dissolution of parliament should not be repeated within one year of the previous one, as this will prevent the executive authority from abusing the right to dissolve parliament and impede the conduct of political life in the country, especially as it has wide discretion to enable it to the dissolution of Parliament, reasoning that in away which may appear to be different, may in fact be identical.

- The researcher calls on the Kuwaiti constitutional legislator to ensure that the ministry, whose parliament was dissolved during its period, should resign because it is consistent with the purpose of establishing the right to dissolve and is consistent with democracy.

- The researcher calls on the Jordanian constitutional legislator to cancel the text that prevents the head of the cabinet who the parliament was dissolved during his period from forming the new following government after the dissolution, because this text is contrary to the purpose of the right and leads to the reluctance of the Prime Minister to request the dissolution of the House of Representatives for fear of losing his position.

\section{References}

Abdul Mut'al, A(2004) Dissolution of Parliament in Comparative Constitutional Systems, 1st ed.Dar al Nahdah,Cairo,p 197.

Abu Zeid, M,A (1988)Dissolution of the House of Representatives (Comparative Study), First Edition, Dar AlNahda Al-Arabiya, Cairo, pp 31-33.

Adaileh ,A,S (2010) Brief in the constitutional system, first edition, House of Culture, Amman,p52.

Ali, I, (1982) Head of State in the Democratic System (PhD Thesis), Cairo University, Faculty of Law, p. 138.

Arnous, Gh,S (2017) The Reality of the Application of the Principle of Commitment between Power and Responsibility, First Edition, Dar Al-Hurun Al-Alami, Amman,p. 475.

Bahri, H,M(2014)The Legal Encyclopedia, Part I, First Edition, Presidency of the Republic of Syria, 1125, p. 534.

Bana,M,A (1988) the Mediator in Political Systems, First Edition, Dar Al-Fikr Al-Arabi, Cairo, p.198.

Baz, B, Ali (2000) The Right to Dissolve Parliament in Contemporary Constitutions, (Comparative Study), Ph.D. Thesis submitted to Tanta University, p. 57.

Fahmi, M(1985), The Egyptian Constitution and the Constitutional Control of Laws, 1st ed., Ma'aref Establishment, Alexandria, p. 485.

Hassan, A F(1986)The Principles of the Constitutional System in Kuwait, First Edition, Dar Al-Nahda AlArabiya, Cairo, p. 381.

Jeeraneh, M, Z(1936) Notes on Constitutional Law, 1st ed., Al-Ahd Press, Baghdad . p. 11.

Khatib, N, A (2017)The Simple in the Constitutional System, Second Edition, Dar Al-Thaqafa, Amman, p. 156.

Kamel,L, M, K(1970) Political Systems (State and Government), 1st ed.Dar al fiker al Arabi,Cairo,p 641.

Kanaan, N(2013) Principles of Constitutional Law and the Jordanian Constitutional System (in accordance with the Constitutional Amendments of 2011), First Edition, Ithraa for Publishing and Distribution, Amman,p. 153 .

Mitwali,A (1964) Constitutional Law and Political Systems, Part I, 3d Edition, Cairo,318.

Murzeh,I(2015) Constitutional Law (A Comparative Study of the Libyan Constitution and the Constitutions of Other Arab Countries), 2nd ed.Dar al Kutob for production ,p 407.

Muslim, Kh, A (1997) The Right to Solution in the Parliamentary System, (Comparative Study) PhD Thesis, 
Cairo University.

Nawalti, B, M (2014) Dissolution of Parliament in Comparative Political Systems, Master Thesis submitted to Damascus University, p. 37.

Nassraween, L, K. Government Resignation after the Dissolution of the House of Representatives, an article published in Jordan's Al-Dustour Newspaper, dated 17 September 2019 on the website:www.alrai.com> article.

Sabri, S(1937) Notes on Constitutional Law, 1st ed., (Without mentioning a publishing house), Cairo, p.298

Sadiq, M(1925) Principles of Egyptian and Comparative Constitutional Law, 1st ed., Dar al-Kitab al-Arabi, Cairo, , p. 299 et seq. Alexandria.

Shatnawi, A, Kh(2013) Political Systems and Jordanian and Comparative Constitutional Law, Book III: The Jordanian Constitutional System, First Edition, Wael Publishing House, Amman ,p.379.

Sheha, (2006), The Status of the Executive in Contemporary Political Systems, First Edition, Al-Ma'arif Establishment, Alexandriap.78.

Shobaki, O, M (2016)Administrative Judiciary, (Comparative Study), Fifth Edition, Dar Al-Thaqafa, Amman, p. 297.

Tamawi, S, M(1996), The Three Authorities in Contemporary Arab Constitutions and Islamic Political Thought, (Comparative Study), 6th Edition, Ain Shams Press.p 526.

Thnibat,M,J (2003) Political Systems and Constitutional Law (with Analytical Explanation of the Jordanian Constitutional System: Rights and Freedoms,first edition.Darr al Thakafa ,Amman p.246.

Website of Kuwait Today Newspaper, Issue No. 292, Thirty-second Year retrieved from :www. Portal.media.gov.kw 